Journal of Law and Religion 35, no. I (2020): 6I-78 (C) The Author(s), 2020. Published by Cambridge University Press on behalf of Center for the Study of Law and Religion at Emory University. This is an Open Access article, distributed under the terms of the Creative Commons Attribution licence (http://creativecommons.org/licenses/by/4.o/), which permits unrestricted re-use, distribution, and reproduction in any medium, provided the original work is properly cited.

doi:I0.IOI7/jlr.2020.9

\title{
THE LEGAL NOTION OF “TRADITIONAL" RELIGIONS IN LITHUANIA AND ITS SOCIOPOLITICAL CONSEQUENCES
}

\author{
EGDŪNAS RAČIUS (1)
}

Professor, Vytautas Magnus University

\begin{abstract}
Lithuania formally distinguishes between what it terms "traditional," "state-recognized," "registered," and "unregistered" religions. Though constitutionally Lithuania is a secular state and all religions are declared equal vis-à-vis the state, religious communities recognized as "traditional" have, nonetheless, been favored by the state. They have been granted preferential treatment both in the legislation and extralegal handling by various state actors and institutions. At the same time, traditional religious communities are formally equal among themselves and vis-à-vis the state. However, the size of their membership puts them into two distinct camps. While the Catholic community constitutes 77 percent of the country's population, the remaining eight traditional religious communities together hardly make up 6 percent, of which 4 percent are Orthodox, with Lutherans, Calvinists, Greek Catholics, Old Believers, Judaists, Karaites, and Sunni Muslims making up the remaining numbers. This article focuses on one of the smaller traditional religious communities, Sunni Muslims, and through this example seeks to show looming complications arising from the current legal system for the governance of religion in Lithuania, which, as a country, starts inter alia being affected by the appearance of revivalist and other "nontraditional" forms of Islam on its territory. The article argues that with the changing makeup of the Lithuanian religious landscape - not related only to Islam - the current system of the governance of religion is not only outdated but also unsustainable and needs to be thoroughly overhauled to come more in line with the developing social reality.
\end{abstract}

KEYWORDS: regime of governance of religion, "traditional" churches and religious organizations, "traditional" religious communities, Islam in Lithuania, Muslims in Lithuania

Though purportedly a secular state, Lithuania nonetheless legally classifies religions on its territory by distinguishing between "traditional" religious communities (and their representative religious organizations) and all others. The foundational law of the country, the Constitution of the Republic of Lithuania (adopted in 1992), makes an explicit distinction in Article 43 between what it refers to as "traditional" and merely "registered" "churches" ${ }^{\mathrm{I}}$ and religious organizations, though, admittedly, it remains silent on which ones fall under which category. ${ }^{2}$

I The term church used in the Constitution is to be understood as a generic term synonymous with "formalized religious hierarchy."

2 Constitution of the Republic of Lithuania I992, article 43, http://www3.lrs.lt/home/Konstitucija/Constitution.htm. 
Lithuania is not unique in post-Communist Eastern Europe. A number of other formerly communist states-among them Montenegro, Albania, Latvia, Poland, Bosnia, Russia, Belarus, Serbia, and North Macedonia - have similar schemes for governing religion by establishing categories of faith communities and organizations. In some (foremost among them, Moldova and Bulgaria), a single church is recognized by the state as the sole religious organization representing the "traditional" faith community of the land, which makes it the de facto established, if not state, religion.

Legal systems employing a traditional/other distinction have encountered competition and problems of instrumentalization. Competing religious collectivities claiming to represent an (entire) "traditional" faith community have brought much chaos into the religious scene of the respective countries and allowed for instrumentalization of faith communities and their religious organizations by political forces for their own, usually narrow, political purposes. For instance, Bulgaria, North Macedonia, and Moldova all have experienced schisms and rivalries between religious collectivities claiming to represent the majority "traditional" (Christian Orthodox) faith community with heavy meddling in their affairs by the governments. Further, both Bulgaria and North Macedonia, along with Serbia, have seen bitter schisms and rivalries in their Islamic communities, with governments playing one against another. Granting "traditional" faith community or religious organization status has also been a thorny issue, with the North Macedonian case being the most traumatic: to be recognized as a "traditional" faith (and ethnic) community, the Muslim population (represented by ethnic Albanians) even went to war with the Slavic-speaking Christian Orthodox majority.

Some Western European countries also have a notion of "traditional" religious organizations, thus distinguishing religious collectivities on their territory into "traditional" and not. In Western Europe, however, problems arise not so much from schisms inside "traditional" faith communities as from "nontraditional" religious collectivities' aspirations for institutionalization and equal treatment by the state. Among such aspiring "nontraditional" religious collectivities in Western Europe, Muslims feature (most) prominently.

Unlike in Western Europe, where the Muslim presence is a rather recent phenomenon and institutionalization of Islam is an even more recent process, in most of Eastern Europe, Lithuania included, Muslims have been present for hundreds of years and Islam has been long institutionalized. Muslim populations and their long-established religious organizations are "traditional," even if not always recognized as such by law. However, recent diversification of Islamic religiosity in Eastern Europe has provided an additional dimension to the understanding of and discussion on what stands behind the notion of a "traditional" faith community and its religious organization when applied to Islam and Muslims. ${ }^{3}$ May there be several antagonistic Muslim collectivities that at the same time are officially recognized as "traditional"? May some of the formerly "traditional" Muslim religious organizations cease to be "traditional" and subsequently stripped off such a status?

In this article, I focus on one of the smaller "traditional" religious communities in Lithuania, namely Sunni Muslims. Through this example, I seek to unpack looming complications arising from the current legal system for the governance of religion in Lithuania as the country experiences religious change, particularly the appearance of revivalist and other "nontraditional" forms of Islam on its territory. I argue that with the changing makeup of the Lithuanian religious landscape (not only related to Islam) the current system for the governance of religion is outdated and

3 Egdūnas Račius, Islam in Post-Communist Eastern Europe: Between Churchification and Securitization (Leiden: Brill, 2020), $125-36$. 
unsustainable and needs to be thoroughly overhauled to come more in line with the developing social reality.

\section{GOVERNANCE OF RELIGION IN LITHUANIA}

\section{Legal Status Quo}

The ambivalence left in the Constitution regarding which religions or faith communities are to be recognized as "traditional" was soon to be rectified by a lex specialis-the Law on Religious Communities and Associations, passed in 1995 (hereafter Religious Communities Law). Article 5 of the Religious Communities Law states: "The State shall recognise nine traditional religious communities and associations existing in Lithuania, which comprise a part of Lithuania's historical, spiritual and social heritage: Roman Catholic, Greek Catholic, Evangelical Lutheran, Evangelical Reformed, Russian Orthodox, Old Believer, Judaist, Sunni Muslim, and Karaite." 4 Although the Religious Communities Law also talks about "state-recognized" religious communities and associations, it refers to them in generic terms, without naming a single one. A third category of religious communities and associations, not referred to in the Constitution, is also discernable: religious communities and associations, which are neither "traditional" nor "state-recognized." In the Religious Communities Law, they are referred to in the context of application for the status of "state-recognized" and none are mentioned by name. ${ }^{5}$ So, while the Constitution does not mention any religious community or association ("church" and "religious organization" in the language of the Constitution), of all the religious communities and associations operating on the territory of Lithuania at the time of the passage of the Religious Communities Law, only those designated as "traditional" are mentioned by name.

One may note a discrepancy in the two texts-while the Constitution talks about "churches" and "religious organizations," the Religious Communities Law consistently uses the terms "religious communities" and "religious associations." Admittedly, churches and religious organizations are formal administrative and spiritual representatives of respective communities. However, while a church or religious organization does not exist without the religious community it represents, the opposite is possible - there may be informal religious communities without a "church" or religious organization. Formal registration with the state naturally requires religious communities to form religious organizations, which, upon registration by the state, become legal entities. It may also occur that the same religious community has several parallel and even rival "churches" or religious organizations. In any case, the discrepancy, which is not only semantic but has legal implications, found in the two most essential texts in regards to the status of religious communities and the governance of religion in the country remains evident and has already caused practical problems discussed further below.

Further, article 43 of the Constitution declares that there is no state religion in Lithuania; thus, all of the traditional religious communities named in the Religious Communities Law are formally equal, both vis-à-vis the state and among themselves. Non-Christian religious communities such as Karaites, Judaists, and Sunni Muslims, with their share in the country's population hovering

4 Law on Religious Communities and Associations of the Republic of Lithuania, article 5, "Traditional Religious Communities and Associations of Lithuania” (No. I-I057/I995), https://e-seimas.lrs.lt/portal/legalAct/lt/TAD/ TAIS. 385299 ?jfwid=I 6j6tpgu6 $\mathrm{W}$.

5 Law on Religious Communities and Associations of the Republic of Lithuania, article 6. "Recognition of Other Religious Associations." 
around or less than o.I percent, formally have the same rights as the Roman Catholic community, which stood at over 77 percent at the time of the last population census in $20 \mathrm{I} \mathrm{I}^{6}{ }^{6}$ In practice, however, the numerically dominant Roman Catholic Church is, to use George Orwell's expression, "more equal" than other "traditional" churches and religious organizations, as it gets preferential treatment from the state and public institutions. For instance, the Roman Catholic Church has its representative on the Council of the national TV and radio broadcaster (LRT), and Roman Catholic priests are routinely invited to consecrate and bless state property (newly opening premises, police cars) and perform rituals at military events (by blessing unit flags). The Roman Catholic Church is occasionally approached, even if not always openly, by state officials for an opinion on important societal issues, and church representatives are invited to governmental working groups preparing new and amending existing legislation. On the social scene, the Roman Catholic Church is a player like no other religious collectivity, and to many Lithuanians it remains not only a spiritual guide but also a social authority. Ultimately, on both the political and social levels, the Roman Catholic Church in Lithuania wields incomparably greater power than any other "traditional" church or religious organization. Therefore, from a sociological point of view, the Roman Catholic Church and other "traditional" churches and religious organizations can hardly be seen as equal among themselves or vis-à-vis the state and the population. Speaking strictly legally, however, neither the Constitution nor the law on religions prioritize the Roman Catholic Church over any other "traditional" church or religious organization.

On the other hand, the very separation of "traditional" religious communities from others raises the question of equality between the former and the latter. Article 3 of the Religious Communities Law assures that "All individuals, regardless of religion they profess, their religious convictions or their relationship with religion, shall be equal before the law. It shall be prohibited to, directly or indirectly, restrict their rights and freedoms, or to apply privileges." 7 Nonetheless, building on the constitutional distinction between religious communities in Article 43 of the Constitution, Articles Io and I I of the Religious Communities Law establish a clear distinction between the two categories of religious communities and associations, not least in respect to the status and rights of their legal persons. ${ }^{8}$ So, for instance, Article I4 clearly prioritizes "traditional” religious communities over "nontraditional" ones by stipulating that

[e]ducational and training establishments of traditional religious communities and associations providing general education of the national standard shall be funded and maintained in accordance with the procedure established by the Government or an institution authorized by it, allocating the same amount of the budget funds as allocated to state or municipal educational establishments of the corresponding type (level). 9

The legally de facto unequal status of religious communities of different categories discernable in both the Constitution and Religious Communities Law, as well as a plethora of subsequent laws that follow it, was challenged at the turn of the century by a group of MPs who approached the

6 Department of Statistics, Gyventojai pagal tautybe, gimtaja kalba ir tikyba [Inhabitants by ethnicity, mother tongue and faith] (Vilnius: Statistics Lithuania, 2013), 5.

7 Law on Religious Communities and Associations of the Republic of Lithuania, article 3, "Equality of People Regardless of their Religion."

8 Law on Religious Communities and Associations of the Republic of Lithuania, article ıо, "Formalization of Legal Personality of Traditional Religious Communities and Associations," and article I I, "Granting of Legal Personality to Other Religious Communities and Associations."

9 Law on Religious Communities and Associations of the Republic of Lithuania, article I4, "Educational, Charity and Benevolent Activities of Religious Communities, Associations and Centres." 
Constitutional Court for an explanation. On two occasions (2000 and 2007), the Court endorsed the status quo promulgated in the Constitution. In its 2000 ruling, the Court ruled that

the provision of Paragraph I of Article 43 of the Constitution providing for the presence of traditional Lithuanian churches and religious organisations is the constitutional basis upon which a different status of traditional churches and organisations may be established if compared with other churches and religious organisations. This means that, without limiting the rights guaranteed for all churches and religious organisations, additional rights for traditional churches and religious organisations may also be ensured by law which are not enjoyed by the churches and organisations which are not traditional. ${ }^{\text {Io }}$

In 2007, explaining its own ruling of 2000, the Court stated that this is possible because

certain rights, which are not enjoyed by other churches and religious organisations recognised by the state, are established to the churches and religious organisations traditional in Lithuania specifically on that constitutional basis that these churches and religious organisations are traditional in Lithuania, and if any other (non-traditional in Lithuania) church or religious organisation is recognised by the state, in itself this does not provide grounds to establish such rights to them, to which churches and religious organisations traditional in Lithuania are entitled because they are traditional in Lithuania. ${ }^{11}$

Ramute Ruškyte, one of the justices of the Court at the time of the 2007 decision, elaborates:

In its decision of 6 December 2007, the Constitutional Court, while construing its previous ruling, emphasised that from the Constitution itself also stems a possibility, while in some cases - the necessity, to establish differentiated legal regulation of corresponding relations with regard to churches and religious organisations that are traditional in Lithuania, as well as with regard to the churches and religious organisations that are recognised by the state, as collective legal subjects. ${ }^{12}$

The inequality between religious communities has become evident in the practical application of the law in various fields. As an example, for the past two decades traditional religious communities have received, through their legal persons, annual payments from the state. The amounts of these payments are determined proportionally, based on the number of believers recorded by the Department of Statistics. The Roman Catholic Church receives the largest payment, with the Orthodox Church being a distant second and the remaining seven traditional religious communities receiving peanuts. It is not the size of the amount that matters here but the fact that the state, in the person of successive governments, has since 1997 distributed such payments exclusively to traditional religious communities though there is no legal basis for that-no law requires the government to financially support any religious community. The "traditional" religious communities

Io Constitutional Court of the Republic of Lithuania June I3, 2000, Case No. 23/98, http://www.lrkt.lt/en/court-acts/ search/I70/taII6I/content (ruling on the compliance of Item 5 of Article I, Paragraphs 3 and 4 of Article Io, Paragraph I of Article I 5, Article 20, Item 2 of Article 2I, Paragraph 2 of Article 32, Paragraphs 2, 3 and 4 of Article 34, Items 2 and 5 of Article 35, Item 2 of Article 37 and Items 2 and 3 of Article 38 of the Republic of Lithuania's Law on Education with the Constitution of the Republic of Lithuania).

I I Constitutional Court of the Republic of Lithuania December 6, 2007, Case Nos. Io/95, 23/98, http://www.lrkt.lt/ en/court-acts/search/I $70 /$ taI $375 /$ content (construing the provisions of a Constitutional Court ruling related with the status of the churches and religious organisations that are traditional in Lithuania).

I2 Ramute Ruškyte, "Legal Aspects of Religious Freedom," in Legal Aspects of Religious Freedom: International Conference, ed. Drago Čepar and Blaž Ivanc (Ljubljana: Office of the Government of the Republic of Slovenia for Religious Communities, 2008), I 49-98, at I 59 . 
may use the received funds at their own discretion and are not required to report to the state on how the funds were spent.

The Religious Communities Law foresees that religious communities may operate without formal registration. However, if they want to become "state-recognized" religious communitiesthat is, to be recognized as "being a part of Lithuania's historical, spiritual and social heritage" - they must first formally register with the Ministry of Justice and become "state-registered" legal persons. Twenty-five years after their first registration, they may apply for the status of state recognized religious community. ${ }^{\mathrm{I} 3}$ But the Religious Communities Law also stipulates that such applicant community needs to have a "back[ing] by society" and the "instruction and rites thereof are not contrary to laws and morality." ${ }^{4} 4$ In the case of rejection, they may reapply after a period of another ten years. ${ }^{15}$ On the other hand, "state recognition . . may be withdrawn, if a respective church or religious organisation recognised by the state loses its support in society or its teaching and practices become contradictory to laws or public morals." I6 Some legal scholars have critiqued both the criteria and the procedure of state recognition (not to be mistaken for state registration). ${ }^{17}$

Though the Constitutional Court in its decision of 2007 made a threefold distinction between "traditional," "state-recognized," and those churches and religious organizations that hold neither of the two statuses, ${ }^{\mathrm{I} 8}$ one may reasonably argue that, in fact, there are four formally distinct categories: (I) "traditional," (2) "state-recognized," (3) "registered" (that is, holding status of legal persons), and (4) unregistered "churches" and religious communities. Of course, one may object to this extension by arguing that being nonregistered does not amount to having the status of "church" or "organization." Here, the discrepancy in the terminology of the two formative texts is once again not only evident but also problematic for practical purposes; religious communities of whichever category (according to the Religious Communities Law) may have "nonregistered" (informal) "churches" or religious organizations.

\section{“TRADITIONAL?” “TRADITIONAL!”: TO BECOME, TO BE AND ... TO CEASE BEING ONE}

As indicated above, the Constitution of Lithuania merely mentions that there are "traditional" "churches" and religious organizations in the country, without specifying them or giving their number. The Religious Communities Law explicitly establishes the number of "traditional" religious communities and names them. It also provides what might be regarded as the grounds (or conditions) for why these particular religious communities have been granted such an exceptional status: they purportedly "comprise a part of Lithuania's historical, spiritual and social heritage." 19

I3 Law on Religious Communities and Associations, article 6.

I4 Law on Religious Communities and Associations, article 6.

I 5 Law on Religious Communities and Associations, article 6.

I 6 Ruškytè, "Legal Aspects of Religious Freedom,” I75.

I7 Mindaugas Lankauskas, "Valstybès ir bažnyčios atskyrimo principas: lyginamieji aspektai ir teisinė padètis Lietuvoje" [The principle of separation between state and church: comparative aspects and legal situation in Lithuania], Teises problemos 63, no. I (2009): 88-I I9.

I 8 Constitutional Court of the Republic of Lithuania (2007), Case Nos. Io/95, 23/98; also Gediminas Mesonis, "Kai kurie konstituciniai valstybès ir bažnyčios santykiụ aspektai" [Some aspects of the constitutional state-church relations], Konstitucine jurisprudencija ıо, no. 2 (2008): I Iо-33, at I I7; Ruškytè, "Legal Aspects of Religious Freedom," I73. 
The Religious Communities Law is an act passed by the Parliament (called Seimas in Lithuanian), which is the ultimate decision maker in regards to which religious communities may or may not be regarded as "traditional" to the country. This is firmly established in the Constitutional Court's decision of 2007 , where it states, "under the Constitution, the Seimas has the powers to name in the law (it not only can, but also must do so) as to which churches and religious organisations are traditional in Lithuania." ${ }^{20}$ This is also attested to in the Constitutional Court's ruling of 2000 , which states, "The constitutional provision that the state shall recognise traditional Lithuanian churches and religious organisations presupposes the fact that the legislature may, in certain cases, name certain religious organisations as traditional in Lithuania." ${ }^{21}$

Hypothetically, the Parliament could have awarded such status to no religious communities, but this would have contrasted with the Constitution, which announces the existence of one or more such religious communities. The Parliament could have awarded such status to just one religious community-naturally, Roman Catholics, who are the overwhelming majority of Lithuania's inhabitants. This, however, would have made Roman Catholicism almost a state religion. Such a choice, arguably, would have still been constitutionally valid, as the Parliament is the sole legal arbiter on the matter of how many and which religious communities may be recognized as "traditional" in the country.22 Alternatively, the Parliament could have sought an amendment to the Constitution that removed the distinction between religious communities. In the end, the Parliament followed the constitutional framework and designated nine "traditional" religious communities, thereby avoiding the scenario of Lithuania having, even if informally or indirectly, a state religion.

While the Parliament has identified nine "traditional" religious communities, the questions of how a religious community may, if at all, become "traditional" and under what circumstances a religious community may lose such status are not addressed in the Religious Communities Law, let alone the Constitution. By default, it is the Parliament that is entrusted to designate future "traditional" religious communities or de-designate current "traditional" religious communities. On the one hand, the Constitutional Court's seminal 2000 ruling is straightforward:

The constitutional establishment of the institute of recognition of churches and religious organisations as traditional means that such recognition by the state is irrevocable. Tradition is neither created nor abolished by an act of the will of the legislature. The naming of churches and religious organisations as traditional is not an act of their establishment as traditional organisations but an act stating both their tradition and the status of their relations with society, which does not depend on the willpower of the legislature. ${ }^{23}$

Therefore, as argued by justice Ruškyte,

in order that the churches and religious organisations, which are traditional in Lithuania, acquire the status of a legal person, the procedure of founding and registering established by the state is not necessary. They are such per se, therefore, under the Civil Code 27 the Regulations of the Register of Legal Persons confirmed by the Government, it is sufficient that they submit a request to include a religious community, association, or a centre, which belong to religions traditional in Lithuania, into the Register of Legal Persons. ${ }^{24}$

20 Constitutional Court of the Republic of Lithuania (2007), Case Nos. 10/95, 23/98.

2 I Constitutional Court of the Republic of Lithuania (2000), Case Nos. 23/98.

22 Mesonis, "Kai kurie konstituciniai valstybès ir bažnyčios santykiụ aspektai," I I9.

23 Constitutional Court of the Republic of Lithuania (2007), Case Nos. 10/95, 23/98

24 Ruškytè, "Legal Aspects of Religious Freedom," I77. 
Such reasoning, however, is very problematic, as the Religious Communities Law refers to broader categories: religious "communities" and "associations," not "churches" or "organizations." In other words, the question is - might there be only nine "traditional" "churches" and religious organizations, each representing one of the nine "traditional" religious communities and associations established in the Religious Communities Law? Or, might there be more such "churches" and religious organizations, provided they are representative of one of the nine communities and associations? Such a question may not seem relevant or even valid in the case of the Roman Catholics, who have no other "church" than the Roman Catholic Church to represent them. However, the second largest "traditional" community-the Orthodox-certainly have more than one "church" or religious organization that they might see as representing them: besides the Moscow Patriarchate, some Orthodox may identify with the Kiev Patriarchate or any other. In the case of Judaists and Muslims, this question is even more relevant.

Hence, the question of the "traditionality" of certain religious communities should not be equated with the "traditionality" of "churches" and religious organizations. It may happen that a group from within a recognized "traditional" religious community founds a new "church" or religious organization that meets both the criteria of "traditional" and "state-recognized" "church" or religious organization referred to in the Constitution and dealt with in more detail by the Constitutional Court in its ruling of 2000 and decision of 2007. Moreover, as Gediminas Mesonis aptly points out, the very "traditionality" of certain religious communities, needs to be first recognized as present before it can be recognized legally. ${ }^{25}$ Lankauskas, in his analysis of the issue of the traditionality of "traditional" religious communities remarks that the Constitution as interpreted by the Constitutional Court holds traditionality to be a "natural 'good,"” 26 something that one may find problematic.

The Constitutional Court has considered the question of naming additional "churches" and religious organizations as "traditional" and decided that

only those churches and religious organisations may be named as traditional in the law, the tradition of which does not raise any doubts, since they are a part of the social, cultural and spiritual heritage of the society formed in Lithuania historically over the centuries; for churches and religious organisations to be recognised as traditional in Lithuania, it is far from sufficient for them, inter alia, to act in Lithuania for several decades or meet other formal criteria established by the legislature, since tradition of churches and religious organisations does not appear even over several generations, but it is a long-term process progressing uninterrupted over the centuries, which should be related with a long-lived spiritual and cultural development of the Lithuanian society and which has an essential impact on it; therefore, in laws the legislature must name those churches and religious organisations as traditional in Lithuania, which undoubtedly correspond to the aforementioned concept of tradition and may not name those churches and religious organisations as traditional in Lithuania, which do not correspond to the aforementioned concept; upon stating and naming in the law, which churches and religious organisations are traditional in Lithuania, the legislature may not expand this list, unless a very long time has passed after such statement and the expansion of such a list would reflect the changed development and status of religious culture of the Lithuanian society; since the tradition of specific churches and religious organisations in Lithuania is an objective status of relations of churches and religious organisations with the society irrespective of the willpower of the legislature, the legislature may not withdraw the statement of the existence of this tradition. ${ }^{27}$

25 Mesonis, "Kai kurie konstituciniai valstybès ir bažnyčios santykiụ aspektai," I I9.

26 Lankauskas, "Valstybès ir bažnyčios atskyrimo principas," Io9.

27 Constitutional Court of the Republic of Lithuania (2007), Case Nos. 10/95, 23/98. 
Following this explanation by the Constitutional Court, one may conclude that though the list of "traditional" religious communities (in the Court's decision called "churches" and organizations) may theoretically be expanded by the Parliament, in practical terms it is seen as a distant and unlikely action.

There is, however, another issue with registering new "traditional" "churches" and religious organizations: the Constitutional Court in its 2007 decision refers to the problem raised by the Ministry of Justice:

in the public administration practice this provision is interpreted as such a definition identifying the criteria of tradition of a religious community or association, based on which tradition is an indicator of the quality of the status of relations with society, i.e. meaning that "traditional religious communities and associations are those which are recognised in society as such," while "the criteria of identifying their tradition should be essentially socio-cultural," although another, alternative criterion for the identification of tradition was used in the public administration practice, specifically, the criterion of institutional succession, in which in identifying whether a community is traditional the last word should be given to a religious community representing the religious trend which is named as traditional. According to the petitioner, situations occur in the public administration practice when a religious community seeks its entry on the Legal Persons Register as traditional, however, it does not belong to a traditional religious association (or has seceded from it) that unites the predominant part of the religious communities practicing the same faith. According to the petitioner, "it is obvious that from the socio-cultural point of view a religious community is a successor of traditions of the same religious tradition, which the legislature named as traditional by Article 5 of the Republic of Lithuania's Law on Religious Communities and Associations and that the society recognises this community as such," and "then it is not clear whether the public administration institution (the Ministry of Justice) is obligated by the Constitution to recognise the tradition of such a religious community, or, based on the criterion of the institutional succession . . . to reject the request of such a religious community." ${ }^{28}$

In this regard, the official of the Lithuanian Ministry of Justice who has been personally supervising registration of religious organizations points to the discrepancy in the terminology referred to above and laments that

there have been a number of problems related to registration of traditional religious communities. The Law on Religious Communities and Associations does not name particular organisations that the state recognises as traditional, it only names confessions in general. When a religious community applies for inclusion into the Register of Legal Entities with a legal form "traditional religious community or association," it is up to the Ministry of Justice to decide, whether a religious community is really traditional or not. The Ministry of Justice either accepts the claim of the new religious community or rejects it; usually the older traditional religious association is against the registration of the new traditional religious association. ${ }^{29}$

Incidentally, this has already happened several times: both Judaist and Old Believer communities have split. The Ministry of Justice, however, following court decisions, has recognized their parallel (and in fact rival) religious organizations as equally "traditional."

In his analysis of the Constitutional Court's ruling of 2000 and decision of 2007 , Mesonis also touches the question of what would happen if a "traditional" religious community splits into several (rival) communities with their own representative organizations headed by parallel

28 Constitutional Court of the Republic of Lithuania (2007), Case Nos. 10/95, 23/98.

29 Donatas Glodenis, "Administrative and Financial Matters in the Area of Religious Freedom and Religious Communities: Case of Lithuania,” in Čepar and Ivanc, Legal Aspects of Religious Freedom, 392-408, at 402. 
administrative and spiritual authorities, all claiming the status of rightful "traditional" communities. ${ }^{\circ} \mathrm{He}$ suggests that such a split could be a good enough ground for the religious community to loose altogether its status as "traditional." ${ }^{\mathrm{I}}$ It is difficult to see why Mesonis thinks so, because the practice has shown that the Ministry of Justice is much more accommodating in such instances, as has happened in the cases of Old Believers and Judaists, when rival "churches" and religious organizations were officially recognized as equally traditional.

As indicated above, according to the Constitutional Court's 2000 ruling, "traditionality" of certain religious communities is declared irrevocable. However, as Mesonis rightly points out, this "irrevocability" is nonetheless conditional-many an article of the Constitution (for instance, Articles 25 and 27) indicate that no religious community may trespass the law. ${ }^{22}$ Consequently, even "traditional" religious communities may be censured for violations of the law, to include stripping them of the status of "traditional" and even banning them in Lithuania. However, for this to happen, the religious community as such needs to have committed continuous grave violations, be they of a criminal nature or pertaining to violations of the administrative, labor, or other law. As it is solely the prerogative of the Parliament to consider stripping a "traditional" religious community of such status, the Parliament, if in doubt of the lawfulness of the activities of a certain "traditional" religious community, arguably, has two options: either to turn to the Constitutional Court for an explanation of the constitutionality of Article 5 of the Religious Communities Law, which explicitly names "traditional" religious communities, or the Parliament could amend the Religious Communities Law itself and wait for the Constitutional Court's ruling on the amendment, if requested by any concerned party. 33

However, if the essential difference between "traditional" religious communities and "churches" and religious organizations claiming to represent them is accepted, then one may talk about "churches" and religious organizations rather than communities as liable to censure all the way to stripping them of the status of "traditional." Once again, arguably, this is hardly applicable to Christian (and definitely not to the Roman Catholic) Churches; however, non-Christian religious communities, foremost Muslim, may be viewed through such a twofold prism, where the religious community is not equated to a religious organization. The peculiarity of Islam in this regard is dealt with in more detail below.

\section{(SUNNI) MUSLIMS AS A “TRADITIONAL” RELIGIOUS COMMUNITY IN LITHUANIA}

As indicated above, Article 5 of the Religious Communities Law includes Sunni Muslims among the "traditional" religious communities of Lithuania. From the point of view of history, this is justifiable-on the territory of Lithuania, there have historically been only Sunni Muslims, chiefly an ethno-confessional group regionally known as Lithuanian Tatars. ${ }^{34}$ Although the Religious Communities Law does not mention Tatars by name, there should be no doubt that they are implied under the designation "traditional" "Sunni Muslims" in the Religious Communities

30 Mesonis, "Kai kurie konstituciniai valstybès ir bažnyčios santykiụ aspektai,” I 24 .

3 I Mesonis, I24.

32 Mesonis, I22-23.

33 Mesonis, I26.

34 On the history of Islam in Lithuania, see Egdūnas Račius, "Islam in Lithuania," in Islam in the Nordic and Baltic Countries, ed. Göran Larsson (London and New York: Routledge, 2009), I I6-32; Egdūnas Račius, "Islam in Lithuania: Revival at the Expense of Survival?," in Muslims in Poland and Eastern Europe. Widening the European Discourse on Islam, ed. Katarzyna Górak-Sosnowska (Warsaw: University of Warsaw Press, 20II), 207-2I. 
Law. The deliberate act on the part of the Lithuanian political elite in the person of the Parliament to include Sunni Muslim Tatars into the category of the national "Us" (or at least, belonging to or with us) can be seen as an expression of the rational politics of inclusion. However, as the letter of the Religious Communities Law is more inclusive, non-Tatar Sunnis by default are also included into the category of this "traditional" religious community.

Although Nira Yuval-Davis maintains that " $[t]$ he politics of belonging involves not only the maintenance and reproduction of the boundaries of the community of belonging by the hegemonic political powers but also their contestation and challenge by other political agents," 35 in the case of the Lithuanian Tatars (that is, "traditional" Sunnis), there appears to be no contestation or challenge by any political or social agents. Apart from the inclusion through formal recognition by the state and its subsequent consequences (like invitations to formal state events and congratulations on festive religious and other occasions) sub-state level actors, like political parties also have set the tone of inclusion of the Muslim Tatar community into the body politic of the country. So, either out of genuine conviction or merely because of the climate of political correctness, none of the Lithuanian political parties have ever expressed any reservations about, let alone dissatisfaction with, the Lithuanian Tatars.

Yuval-Davis claims that while the politics of belonging "comprises specific political projects aimed at constructing belonging in particular ways to particular collectivities," these collectivities simultaneously are "themselves being constructed by these projects in very particular ways." ${ }^{6}$ In other words, the politics of belonging inevitably affects both self-identification and narratives of belonging among groups under consideration, in this case, Lithuania's Muslim Tatars, and the general understanding of "boundaries of belonging." In this perspective, one can safely argue that Islam, as embodied by the Lithuanian Tatars, is seen by the state and the majority of the society as being within these boundaries - that is, "traditional" to the country and certainly to "comprise a part of Lithuania's historical, spiritual and social heritage." 37

At the same time, following the letter of the Religious Communities Law, all non-Sunni Muslims by default fall into the category of "nontraditional" religious communities. Ultimately, from the legal point of view, Muslims in Lithuania fall into two distinct categories: the "traditional" religious community, comprising besides the historical Sunni Tatars all other Sunnis irrespective of their cultural background or place of origin, and "non-traditional" religious community(ies) composed of non-Sunnis of whatever origin and cultural background. Following Article 6 of the Religious Communities Law, any non-Sunni Muslim community might expect to become a "state-recognized religious community," but such recognition requires both a twenty-five year waiting period from the initial registration and "widespread support" in the society. There is, however, another option-to register as a public enterprise rather than as a religious community / organization.

\section{THE NUMBERS GAME AND THE CONTENTS OF ISLAM PRACTICED IN LITHUANIA}

Lithuanian Tatars are the historical backbone of the country's more than six-hundred-year-old Muslim community; however, according to the most recent (20II) population census results, just over half of Lithuania's Sunni Muslims-I,44I (or 52.8 per cent) of the total 2,727-are

35 Nira Yuval-Davis, "Belonging and the Politics of Belonging," Patterns of Prejudice 40, no. 3 (2006): I97-2 I 4, at 205 .

36 Yuval-Davis, "Belonging and the Politics of Belonging," 97.

37 Law on Religious Communities and Associations, article 5. 
Tatars. The 20I I census also revealed that the number of ethnic Tatars in the country decreased by I 3.7 per cent in a decade: from 3,235 in $200 \mathrm{I}$ to 2,793 in $20 \mathrm{II}$ and only $5 \mathrm{I} .6$ per cent of them identified with Islam in $201 \mathrm{I} .3^{38}$ The second largest ethnic group among the Lithuanian Sunni Muslim community in 20I I was Lithuanians with 374 (in 200I, it was I 85 ) Sunni Muslims, ${ }^{39}$ presumably of convert background. There also were 73 ethnic Russian and I 5 ethnic Polish Sunni Muslims (many if not most of whom were also of convert background), with 794 (from among I 57 Uzbeks, I44 Kazakhs, 93 Arabs, 88 Turks, 84 Bashkirs, 76 Chechens, 43 Tajiks, 30 Turkmens, 29 Egyptians, I9 Pakistanis) assigned to a general category "other" Sunnis. There were also 648 Azerbaijanis in the country at the time of the census, but it is not known how many of them, if any, identified as Sunni Muslims.

The official statistics, however, are indirectly contested by the Tatar Muslim leadership ${ }^{40}$ who tend to claim that all Tatars in Lithuania are Muslims though some for various personal reasons chose not to indicate their belonging to the Islamic faith in the population census. If accepted, such claim would raise the number of Muslims in Lithuania at the time of the census by some I, 350 individuals. Likewise, some Tatars tend to believe that there might be even more ethnic Tatars (and, by extension, Muslims), though, like in the case of religious identification, some chose to conceal their true ethnicity. On the other hand, some Tatars are reluctant to accept Lithuanian converts to Islam as true Muslims, ${ }^{4 \mathrm{I}}$ considering only those who were born in Muslim families as true Muslims. Thus, while many persons of Central Asian background may have not indicated a Muslim religious identity during the census, for many Tatars, they are still Muslims or at least of Muslim background. Likewise, the census appears to have missed big parts of ethnic groups of migrant background-there were definitely many more Sunni Muslim Arabs and Turks at the time of the census than indicated in its results (93 and 88, respectively), most of whom were neither citizens of Lithuania nor its permanent residents but rather temporary expatriates-students, businessmen, spouses and others. Finally, although the census results returned 374 ethnic Lithuanian Sunni Muslims, the total number of converts to Islam and their progeny who are citizens of Lithuania is much higher. Admittedly, though, a big part of them live outside of Lithuania and technically are not residents of Lithuania and therefore not included in the census results (as all other Lithuanian émigrés). For instance, the British population census of 20II alone revealed that there were 535 Muslims who had come to England and Wales from Lithuania between $200 \mathrm{I}$ and $20 \mathrm{II} .4^{2}$ Although some of those emigrants are definitely of Tatar ethnicity, ethnic Lithuanians must also feature prominently. Thus, speaking globally, there are more Muslims of either ethnic Lithuanian background or Lithuanian citizenship or origin than the national census figures reveal.

In the end, the number of people of Muslim background residing at any given moment in Lithuania is significantly higher than the statistically counted number of Sunni Muslims in the country. If citizens of the country of Muslim background residing abroad are added, the total number becomes even greater. Irrespective of the numbers, the Lithuanian Muslim umma may be seen

38 Department of Statistics, Lithuanian 20 I I Population Census in Brief (Vilnius: Statistics Lithuania, 2012 ), 20.

39 Department of Statistics, Gyventojai pagal tautybę, gimtaja kalba ir tikyba, I4

40 This claim is based on the author's personal communication with Lithuanian Tatars over the years.

4I Author's personal communication with Lithuanian Tatars over the years.

42 UK Office for National Statistics, Table CT0265_20I I: Country of Birth by Year of Arrival by Religion-England and Wales (November 20I4), http://webarchive.nationalarchives.gov.uk/20I60II02000I6/http://www.ons.gov. uk/ons/about-ons/business-transparency/freedom-of-information/what-can-i-request/published-ad-hoc-data/census/ ethnicity--identity--language-and-religion--eilr-/index.html, accessed December 20, 2017 (data no longer available). 
as being composed of four distinct, and, as discussed below, often disconnected, segments. In order of their size, these segments are (I) Lithuanian Tatars; (2) people of Muslim background who came from Central Asia, Caucasus, or other Muslim-inhabited regions of the then Soviet Union to settle in Soviet Lithuania, and their progeny; (3) expatriates and recent immigrants of Muslim background, and (4) ethnic Lithuanian, Polish, and Russian converts to Islam and their progeny.

In view of this demographic information, one may draw the following conclusion: Islam in Lithuania is still first and foremost represented by the more than half a millennium old Lithuanian Tatar segment; however, with their numbers dwindling and the steady increase in the ethnic Lithuanian and other convert component, the face of Islam in Lithuania is slowly but surely changing. If, or when, Lithuania becomes a more attractive destination for migrants from the Muslim-majority lands, the demographic balance may take yet another turn. However, though the population census counted Sunni Muslims (and there is no data on the non-Sunni Muslim population, purportedly because it is statistically negligent), it has nothing to say on either the form or intensity of Islamic religiosity practiced by them.

As of 2018 , of the nine officially registered Muslim religious communities in Lithuania recognized under the category "traditional religious community," only five had the word "Sunni" in the title. Irrespective of whether the word "Sunni" is or is not present in their title, all nine registered Muslim communities were, at least nominally, Sunni. Either their representatives were the founding fathers of or the founding of these communities themselves was endorsed by the pan-Lithuanian umbrella Sunni Muslim organization, the Spiritual Center of Lithuanian Sunni Muslims, also known as the Muftiate. The Muftiate itself was founded in 1998 in direct reaction to Article ro of the Religious Communities Law, 43 and its board includes representatives of these communities. The founding fathers of the Muftiate were Lithuanian Tatars who made sure the title of the organization included the word Sunni, in order to ensure that the Muftiate would be recognized as a legal entity representing a "traditional" religious community in the country, namely Sunni Muslims. ${ }^{44}$ Article I.I of the Muftiate's Statute states that the Muftiate is "the supreme governing body of Lithuanian Sunni Muslims," 45 implying that all current and future Sunni communities and organizations (presumed by default to fall under the category of "traditional religious community") are to be subordinated to the Muftiate, and that there may be no rival or alternative "supreme governing body" or Muftiate.

Though the Muftiate claims, through its statute, to espouse the normative Sunni Islam of the Hanafi legal tradition, to which Lithuanian Tatars ascribe themselves, the research reveals that the overwhelming majority of Lithuanian Tatars are either irreligious to the point of agnosticism or even atheism, or practicing Islam but with very little knowledge of what many would consider orthodox Sunni Islam. ${ }^{6}$ Historical forms of Islamic religiosity practiced by Lithuanian Tatars fall, rather, under the category of "folk Islam." 47 These practices, however, were almost wiped away by the crippling Soviet religious policies and have hardly been revived in the post-Communist period.

43 Law on Religious Communities and Associations, article ro.

44 Galimas Sitdykovas, "Lietuvos musulmonu sunitu dvasinis centras atkurtas" [The spiritual center of the Lithuanian Sunni Muslims reestablished], Lietuvos Totoriai I8, no. I (I999): I, 3, at I.

45 Spiritual Center of the Lithuanian Sunni Muslims-Muftiate, Articles of the Spiritual Center of the Lithuanian Sunni Muslims-Muftiate, I998 (on file with the author).

46 Egdūnas Račius and Tamara Bairašauskaitè, "Lithuania," in Muslim Tatar Minorities in the Baltic Sea Region, ed. Ingvar Svanberg and David Westerlund (Leiden: Brill, 20I6), 2I-45, at 33 .

47 Stanisław Kryczyński, Tatarzy litewscy. Próba monografii historyczno-etnograficznej [Lithuanian Tatars. An attempt at historic-ethnographic monograph] (Warszawa: Wydanie Rady Centralnej Związku Kulturalno-Oświatowego Tatarów Rzeczypospolitej Polskiej, I938), I72-210, 28 I-308. 
Unlike Tatars, many (if not the overwhelming majority) of ethnic Lithuanian Muslims (converts) are very religious. However, though many might identify with Sunnism, there is a significant segment who identify with some revivalist trend, this way effectively going beyond what would be commonly held as Sunni identity, beliefs, and way of living. ${ }^{8}$ Some from among the expatriates and immigrants are also of revivalist leanings, though many are nominally Sunnis.

Since Lithuania regained independence in 1990 , there has been only one attempt to register a non-Sunni Muslim organization in the country. In the early I990s, before the Religious Communities Law was passed, an Ahmadi community applied for registration. And though the Ahmadi community was formally registered with the state, from testimonies of local Tatar Muslims, it appears that the organization never actually existed as a functioning entity and no activities were carried out in its name. No Shi'i denominations have yet attempted to formalize their presence in Lithuania in the form of registering a religious community. This despite the fact that there are well over five hundred Lithuanian citizens of Azerbaijani origin, some, if not most, of whom may be of Shi'i Ithna 'ashari (Imami) cultural background, as well as several dozen other individuals of Shi'i, mainly also Ithna 'ashari (Imami), cultural background.

\section{THE PECULIARITY OF ISLAM AS A “TRADITIONAL” RELIGION}

The regime of the governance of religion in place in Lithuania presupposes several common features attributed to all "traditional" religious communities. One "traditionality" has already been addressed above. Another is the structural organization of these communities, in the Constitution itself referred to as "churches" and religious organizations. However, both notions are problematic when applied to Islam.

If, as argued by the Constitutional Court, "traditionality" is a historical fact, the Sunni Muslim community, as represented by the Lithuanian Tatars, is without a doubt traditional and has been rightfully recognized as such. However, traditionally Lithuanian Tatars had no religious organizations, unless their autonomous village congregations, centered on local mosques, could be considered informal, incipient religious organizations. As has been documented by researchers, the Lithuanian Tatar Muslim community had not formed a formal unitary organization until the I920s, when they founded a Muftiate. ${ }^{49}$ However, one needs to be reminded that this took place in the Polish state, not Lithuania, which at the time controlled the Vilnius region with its sizeable Muslim Tatar population. In the interwar period, some Muslims of the Republic of Lithuania made attempts at institutionalizing Islam in the country, but all of those attempts failed, chiefly, due to internal strife in the Muslim community itself..$^{\circ}$ In view of this, one may hardly talk about the "traditionality" of a Sunni Muslim organization in the Lithuanian state. Though the Muftiate, which was founded in 1998 in the Lithuanian capital Vilnius, may be seen as a symbolic heir of the Polish-era Muftiate that operated in the city between I 925 and 1939, speaking strictly legally, it was a foreign organization. This is why the Lithuanian authorities abolished it once Vilnius became part of the Lithuanian state in late I939. Therefore, rather than regarding the present

48 Egdūnas Račius and Vaida Norvilaitè, “Features of Salafism among Lithuanian Converts to Islam,” Nordic Journal of Religion and Society 27, no.I (2014): 39-57, at 46.

49 Kryczyński, Tatarzy litewscy, 54; Tamara Bairašauskaite, Lietuvos totoriai XIX amžiuje [Lithuanian Tatars in the nineteenth century] (Vilnius: Mintis, I996), I30-50.

50 Tamara Bairašauskaitè, "Musulmonụ konfesinè bendruomenè nepriklausomoje Lietuvoje” [Muslim confessional community in independent Lithuania], Lietuvos istorijos metraštis I99I (I992): 98-II4. 
Muftiate as a "traditional" Sunni Muslim organization in Lithuania, one needs to be fair and accept it as an innovation, both in form and contents.

On the other hand, the concept of the present Lithuanian Muftiate is directly inherited from the interwar Polish Muftiate, which was ultimately accepted by the Polish state as nothing less than a Muslim "church." The 1936 agreement between the Polish state and the Muslim community of the country elevated the Muftiate to the status of the sole Islamic spiritual-administrative authority with the status of mufti almost akin to that of bishop. The founding fathers of the Lithuanian Muftiate in the latter part of the I99os sought to make it also the sole representative of the country's Sunni Muslims, in essence, a "church."

However, anyone knowledgeable about Islam would point out that such practices of churchification of Islam and ecclesiastification and bureaucratification of Muslim spiritual leadership, though certainly not a novel phenomenon in Europe ${ }^{5 \mathrm{I}}$ and the broader world, are very often objected to and contested by many Muslims themselves, as this touches the question of the very nature of Islam. Many a Muslim (and researchers alike) would argue that even normative Islam does not have clergy in the Christian sense of the word and therefore may not have a hierarchical ecclesiastical structure reminiscent of Christian churches. ${ }^{52}$

Furthermore, both the Constitution and the Religious Communities Law appear to imply that "traditional" religious communities are fixed entities with little perspective of evolution, let alone heterolinearity. Islam, time and again, has proven to be a very vibrant religion with multiple parallel, rival, and even mutually excommunicationist (takfir-inclined) trends constantly emerging, evolving, and falling into oblivion. With the absence of institution(s) vested with the monopoly of dogma, and certainly after the abolition of the institute of khalifa in the I920s, the global Muslim commonwealth today is as fragmented as it probably has ever been in history. And most of that fragmentation (and the ensuing antagonism) happens within the Sunni branch of Islam to which the overwhelming majority of the world's Muslims ascribe themselves. In consequence, to identify one particular strand of Islam as "traditional" becomes very problematic.

One may argue that what is understood as "traditional" Islam in Lithuania is precisely the (once) Tatar-practiced forms of Islamic religiosity, without any inferences to universality. With the changing composition of the Muslim population in the country-both in terms of origin of actively practicing Muslims and the contents of their practiced Islam-the question becomes whether the Islam practiced in Lithuania is the same Islam which is implied in the Religious Communities Law, that is, "traditional"?

The Ministry of Justice, in cases of new applications for the status of "traditional" Sunni Muslim organizations, has been consulting the Muftiate and seeking its informal imprimatur or at least nibil obstat. Until 2018, there had been no instance of objection by the Muftiate to recognition of a Muslim religious organization as a "traditional" religious community or refusal by the Ministry to register it as such. However, as noted by Donatas Glodenis, the Religious Communities Law (or indeed any other piece of legislation) does not explicitly name the Muftiate as the umbrella or supervising Sunni Muslim organization in the country. ${ }^{53}$ So, at least formally, alternative or rival Sunni Muslim muftiates or other organizations may be registered at the ministry's discretion

5 I Račius, Islam in Post-Communist Eastern Europe.

52 Taha Jabir al-Alwani, "Author's Introduction," in Towards a Fiqh for Minorities: Some Basic Reflections (London: International Institute of Islamic Thought, 20I0), xiii-xxiii, at xvi; Mark Sedgwick, "Is There a Church in Islam?," ISIM Newsletter, no. I3 (2003): 40-4I.

53 Donatas Glodenis, "Administrative and Financial Matters in the Area of Religious Freedom and Religious Communities: Case of Lithuania,” in Čepar and Ivanc, Legal Aspects of Religious Freedom, 392-408, at 402. 
as Sunni Muslim "traditional" religious communities. But on what basis the ministry is to decide whether a religious community is really traditional or not remains unclear, as the criteria implied in the Religious Communities Law, ${ }^{54}$ and also elaborated by the Constitutional Court, namely that the applicant community is to "comprise a part of Lithuania's historical, spiritual and social heritage," 55 is very vague. On the other hand, as indicated above, both Judaist and Old Believer communities have rival legal persons with equal status vis-à-vis the state of traditional religious communities. Moreover, one of the Judaist communities, Habad Lubavich, in fact, has never had a historical presence in Lithuania and from the historical point of view hardly qualifies as a community that makes up "a part of Lithuania's historical, spiritual and social heritage." 56 With this precedent in mind, one should not be surprised if, or when, an alternative Sunni Muslim religious community not only applies for the status of a "traditional" religious community but is eventually granted it.

Such prospective development inevitably would lead to complaints by the already existing Muftiate and its rejection of a parallel or rival muftiate, something that has already occurred in a number of Eastern European countries-Serbia, Poland, Belarus, Ukraine, and Slovenia, to name just a few. 57 The situation would be even more aggravated if the new organization followed an exclusivist and uncompromising revivalist school, such as Salafism or Wahhabism.

This raises the question, under what circumstances, if at all, the Sunni Muslim community in general or a particular (officially registered) Sunni Muslim religious organization may be stripped off of its status as "traditional"? For instance, could an organization be stripped of status if Muslims (and particularly their leadership) claiming to be Sunni (and by extension a "traditional religious community") start behaving in a manner which does not enjoy the support of the majority of the society and is not (anymore) held by it to "comprise a part of Lithuania's historical, spiritual and social heritage" referred to in the Religious Communities Law. Though at present this might seem to be a distant possibility, if the tectonic demographic shifts in the composition of the population of Muslim background continue, Lithuanian Tatars will simply lose the person power to keep leadership in their hands and with it the monopoly of the publicly presented contents of Islam practiced in the country. But even before that, nascent Salafist and other revivalist-leaning groups are already forming and considering registering with the state, if possible, as representative organizations of (at least a segment of) the "traditional" religious community of Muslims.

The Religious Communities Law (Article 20) envisions the procedure for the closure of religious organizations by the court. However, it speaks in general terms and does not separately elaborate on the case of "traditional" religious communities. Apparently, it would be the court's prerogative to decide on the matter; however, like in the case of registration or refusal thereof of an applicant community by the Ministry of Justice, the court would have to come up with more solid evidence than that the religious organization or the entire community no longer "comprise[s] a part of Lithuania's historical, spiritual and social heritage." In any case, the court would have to deal with the claims and behavior of the community under question, which, unless they were terrorismrelated, would very likely be presented by the organization itself as a practice required by nothing less than Islam.

54 Law on Religious Communities and Associations, article 5.

55 Law on Religious Communities and Associations, article 5.

56 Law on Religious Communities and Associations, article 5.

57 Egdūnas Račius, Muslims in Eastern Europe (Edinburgh: Edinburgh University Press, 2018), 63-65, 74-75, 96-97, I I I-I2, I38; Račius, Islam in Post-Communist Eastern Europe. 


\section{CONCLUSIONS}

Of all the "traditional" religious communities, it is the (Sunni) Muslim that appears to be least fitted for the present system of the governance of religion in Lithuania. As argued above, the effective churchification of Islam through the Religious Communities Law is counterproductive as it fails to recognize the wider social reality-the multiplicity of parallel (and even rival) forms of Islamic religiosity that claim to be truly "Sunni."

As long as the Muslim community remains both numerically insignificant and, more importantly, reluctant to push for the implementation of more religious rights implied (or presumed to be included) in the recognition of (Sunni) Islam by the state as a "traditional" religion in the country, the comfortable status quo, with Sunni Islam remaining recognized as a "traditional" religion in the country, will not be upset. However, when more observant (and thus demanding) Muslims (prospectively, of convert or immigrant background) either ascend to the power positions within the existing community structures or create their own alternative power bases and proceed to claim the presumed rights, the status of Islam in the country will inevitably start changing significantly, both on the official and public levels, as this would cause friction and tension not only between the officially secular state and the generally post-religious majority, on the one side, and the increasingly visible observant part of the Muslim minority, on the other side, but within the Muslim community itself.

Even without the emergence of alternative and rival Muslim organizations claiming to be "traditional," the constitutional division of "churches" and religious organizations into "traditional" and "nontraditional" has already caused legal problems - at least two "traditional" religious communities have split to form antagonistic "churches" and religious organizations. However, both Old Believers and Judaists not only comprise a very small percentage of the country's population, but both are diminishing in numbers, without much prospect of reversing the decline. One may even expect that, in the not so distant future, these two communities may follow the Karaites' trail-diminish to negligible numbers that can no longer sustain any communal religious activities. The Muslim community, on the contrary, is expected to grow, first of all, through immigration of people of Muslim background from Asia and Africa but also through conversion of Lithuania's citizens.

The Ministry of Justice, realizing the outdatedness of the Religious Communities Law and the unsustainability of the current system of governance of religion in the country, has already started considering amendments to the Religious Communities Law. Among other approaches, they were to profoundly reconsider the constitutionally enshrined division between "traditional" and "nontraditional" religious communities. However, the draft amendments have never reached the floor to be voted on by the Parliament. On the other hand, any serious and thorough reconsideration of the system of governance of religion in Lithuania is possible only with the amendment of Article 43 of the Constitution, something that the Roman Catholic Church would vehemently oppose, and there is no political power or will to overcome such an opposition. Therefore, for the foreseeable future, it seems that Lithuania is stuck with nine "traditional" religious communities, among them Sunni Muslims. It remains to be seen how the ongoing demographic, ideological, and organizational changes in the Muslim population of Lithuania will affect the status quo. One, however, should be in no doubt, they will, and profoundly.

The Lithuanian case of the regime of governance of religion with its entrenched distinction between "traditional" and "nontraditional" "churches" and religious organizations, though it may be seen unique in some respects, is representative, if not symptomatic, of a cluster of Eastern European states that have similar regimes, and particularly those that include Muslim 
collectivities in the category of "traditional" religious communities and organizations. Such regimes of governance of religion, as shown by the Lithuanian case, are very problematic, if not counterproductive, because, application of the label and status of "traditional" religious organization to Muslim religious collectivities, in light of rapid diversification of forms of Islamic religiosity found in most of post-Communist Europe, is altogether untenable. Some Eastern European have already experienced splits and rivalries in their Muslim communities, which have led not only to the fragmentation of the domestic Islamic religious scene but also claims and counterclaims (and attached political manipulations) of representing true, if not "traditional," forms of Islamic religiosity. Thus, it becomes increasingly difficult to define what "traditional" Islam means and who represents it, obscuring the very dichotomous paradigm of "traditional"/"nontraditional" religious communities and their organizations. 